\title{
CORRECTION
}

\section{Correction to: methanogenic biodegradation of crude oil storage tank sludge enhances bio-corrosion of mild steel}

\author{
Okoro Chuma Conlette ${ }^{1} \cdot$ J. N. Nnaji Nnameka ${ }^{2}$ \\ Published online: 10 October 2018 \\ (c) Springer Nature Switzerland AG 2018

\section{Correction to: \\ Euro-Mediterranean Journal for Environmental Integration (2018) 3:34 \\ https://doi.org/10.1007/s41207-018-0077-6}

In the original publication, Figs. $2 \mathrm{a}-\mathrm{c}$ and $3 \mathrm{a}-\mathrm{c}$ are not correct. The correct Figs. $2 \mathrm{a}-\mathrm{c}$ and $3 \mathrm{a}-\mathrm{c}$ are given below.

The original article can be found online at https://doi.org/10.1007/ s41207-018-0077-6.

Okoro Chuma Conlette

chuma2k2001@yahoo.com; chuma.okoro@funai.edu.ng

1 Department of Biology, Microbiology and Biotechnology,

Federal University, Ndufu-Alike, Ikwo, Ebonyi State,

Nigeria

2 Department of Chemistry and Biochemistry, Federal

University, Ndufu-Alike, Ikwo, Nigeria 
Fig. 2 GC Chromatograms of oil sample subjected to anaerobic methanogenic degradation without substrate enhancement at day 0 (a; oil content $=4800 \mathrm{ppm})$, day $30(\mathbf{b}$; oil content $=3600 \mathrm{ppm}$ ) and day $60(\mathbf{c} ;$ oil content $=1800 \mathrm{ppm})$. Time in minutes
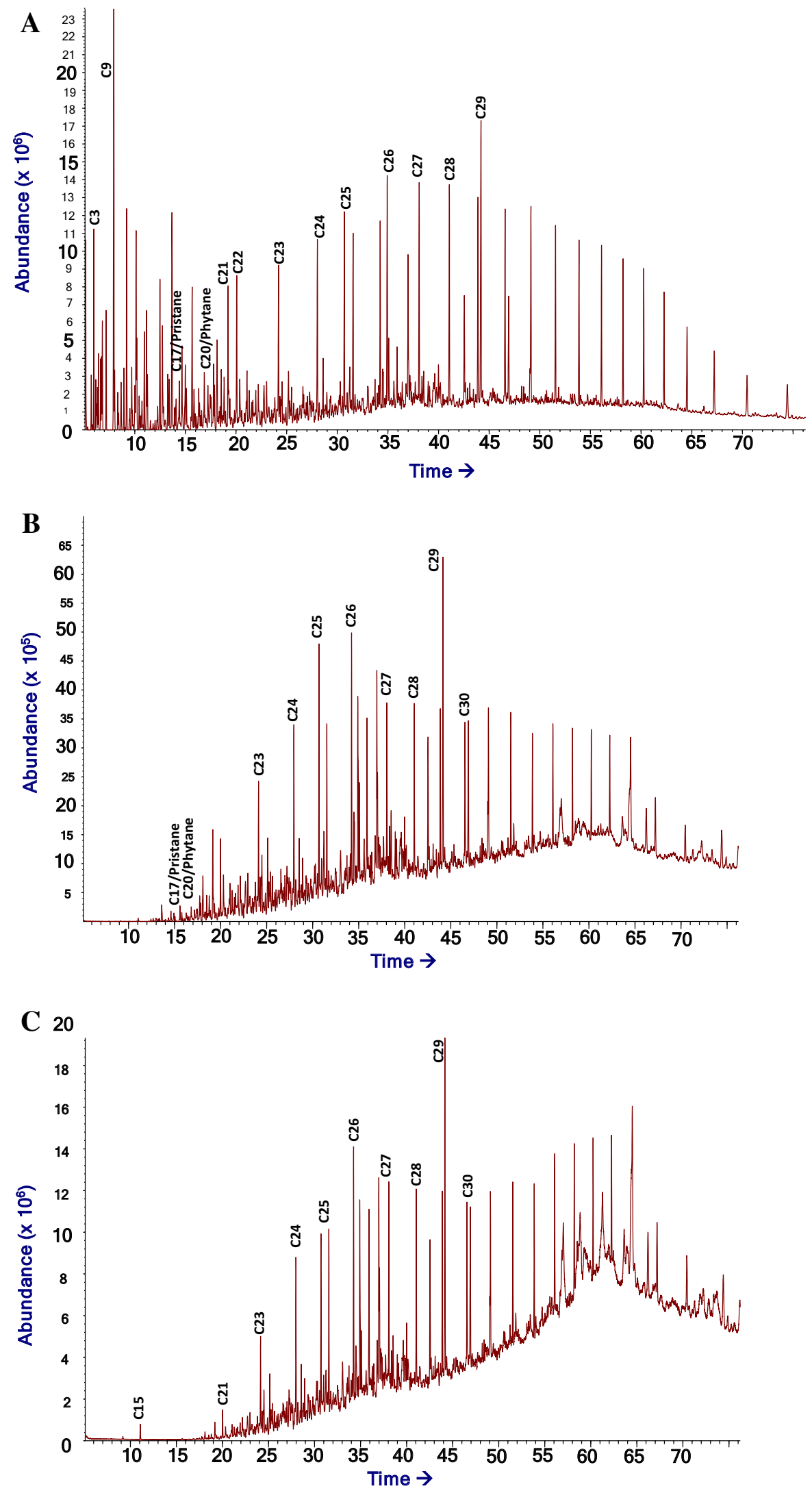
Fig. 3 GC Chromatograms of oil sample subjected to anaerobic methanogenic degradation with substrate enrichment (acetate $+\mathrm{H}_{2}$ ) at day 0 (a; oil content $=4800 \mathrm{ppm})$, day $30(\mathbf{b}$; oil content $=1670 \mathrm{ppm}$ ) and day $60(\mathbf{c} ;$ oil content $=285 \mathrm{ppm})$.

Time in minutes
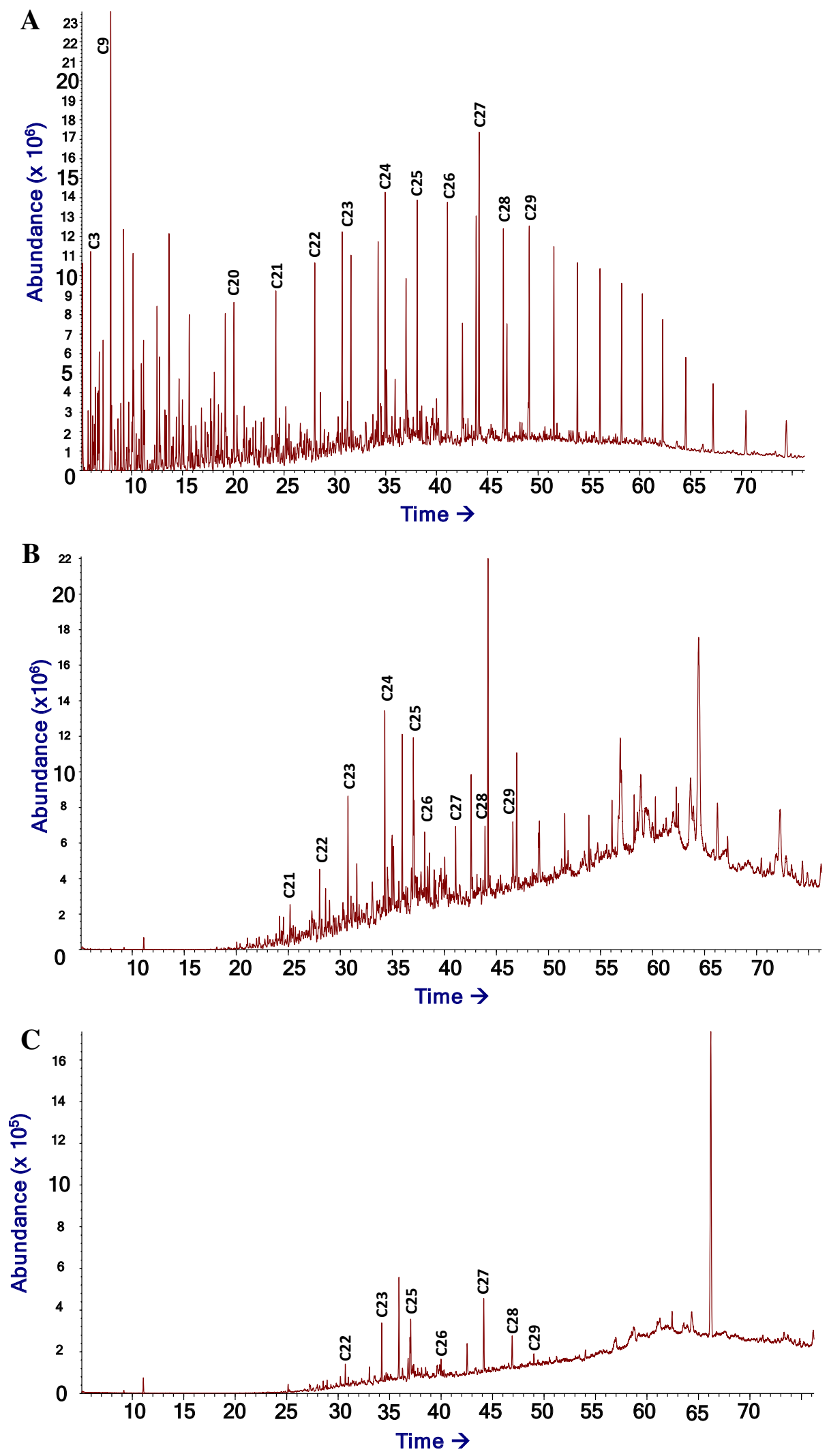